\title{
Strategy development: Case study on two cultural villages in Bali
}

\author{
Nyoman Indah Kusuma Dewi ${ }^{1^{*}}$, I Putu Astawa ${ }^{2}$, I Wayan Siwantara ${ }^{3}$, I Gusti Agung Bagus \\ Mataram $^{4}$ \\ ${ }^{1,3}$ Department of Business Administration, Bali State Polytechnic, Bukit Jimbaran, Kuta Selatan, Badung, Bali, Indonesia \\ ${ }^{2,4}$ Department of Tourism, Bali State Polytechnic, Bukit Jimbaran, Kuta Selatan, Badung, Bali, Indonesia
}

\section{Keywords \\ Cultural village \\ Attractions \\ Accessibility \\ Amenities \\ Strategy \\ Cultural tourist}

Received: 8 November 2017

Accepted: 15 November 2017

Published: 4 December 2017

\begin{abstract}
This study aims to compare the strategy development of cultural villages that have different types of attractions, whether there is any characteristic difference of cultural village strategy in terms of attractions, accessibility, amenities, and ancillary aspect. Two cultural villages with different tourism attractions were used as a case study; those are Kamasan cultural village in Klungkung Regency with handicraft attractions and Pemuteran cultural village in Buleleng Regency with marine activities (adventurous tourism). The study was conducted qualitatively with the case study approach by comparing cases with very different types of attractions. The data was collected by in-depth interview, observation, and documentation with qualitative descriptive analysis technique (Miles and Huberman, 1994). Interviews were conducted with business actors and tourists by using the random sampling method. The interview was ended when data reached saturation. The finding revealed differences in the strategy development of cultural villages, particularly in the characteristic of amenities (i.e., homestay, hotel, inn, and villa). A Cultural village with handicraft attractions has very few accommodations because tourists usually visit for a short time and have a specific interest in arts and culture (purposeful type of cultural tourist). While the cultural village with marine activities has a large number of different types of accommodations. The majority of tourists spend more time to experience the adventure (sightseeing and casual cultural tourists) .
\end{abstract}

(C) 2017 The Author(s). Published by TAF Publishing.

\section{INTRODUCTION}

Community Based Tourism (CBT) has been the main concern of many countries as the fundamental factor of tourism initiatives (Lucchetti and Font, 2013; Pathumporn and Nakapaksin, 2015; Yusof et al., 2012). CBT is defined as economically, environmentally, socially, and culturally responsible visitation to local/indigenous communities to enjoy and appreciate their cultural and natural heritage, whose tourism resources, products, and services are developed and managed with their active participation, and whose benefits from tourism, tangible or otherwise, are collectively enjoyed by the communities (Boonratana, 2010). Similarly, Kontogeorgopoulos et al. (2014) defined the literature of CBT include most or all of the characteristics: "environmental sustainability, community participation, equitable distribution of financial benefits, community empowerment, improvements in standard of living, and community management, control, and ownership of tourism projects." In this regard, CBT emphasizes on participation of local communities of tourist destination which in the end improve their quality of life by allowing tourists to get in touch with their daily life and learn the culture (Lucchetti and Font, 2013). Community participation

\footnotetext{
${ }^{*}$ Corresponding author: Nyoman Indah Kusuma Dewi

†Email: ikdewi@pnb.ac.id
} 
could be in form of cooperative or individually own and manage business to collaboration between the community and the private sector (Niesing et al., 2016; Lucchetti and Font, 2013). By this, community in the tourist destination actively own and manage tourism business to improve their quality of life. Community participation has been discussed by many academia covering namely its barriers (Aref and Redzuan, 2004); tourism planning and development (Bahaire and Elliott-White, 1999); arguments (Timothy and Tosun, 2003); opportunities and constraints (Goodwin, 2002); conception and use (Okazaki, 2008); limitations (Tosun, 2000); and nature (Tosun, 2006).

The concept of CBT in Indonesia has been implemented to cultural village initiative. The Indonesian government plans to increase the number of cultural village in Indonesia in year 2015-2019 to about 4000 cultural villages (Kompas, 2016). In 2017 alone, the government attempted to increase the number of cultural villages from 1.902 villages that have potential to be developed (Ministry of Domestic Affair, 2017). Indonesian government facilitates villages that have the potential and meet the requirements for being a cultural village by offering financial support, human resources training, rules and regulation and proper infrastructure. There are four major requirements, known as 4 A's, to establish a cultural village that are attractions, accessibility, amenities and ancillary (Andrianto and Sugiama, 2016). A cultural village should have attractions to attract tourists for coming, easy to access; there are amenities (i.e., accommodations, restaurants, tourist information and other supporting infrastructure) and ancillary to provide ultimate service for cultural tourists to enjoy the experiences provided by the village. In line with the Indonesian government initiative, Bali, the most popular tourist destination in Indonesia, develops cultural village intensively. In 2017, there are 67 cultural villages with different kind of attractions (Kompas, 2017). Tourist attractions could be nature, unique culture, and specific attractions (Hiransomboon, 2017; Andrianto and Sugiama, 2016). These different tourist attractions may lead to different strategic development of cultural villages. This research is done to find out the differences of destination strategic development of cultural village based on attractions, accessibility, amenities and ancillary aspect.

\section{LITERATURE REVIEW}

Defining Cultural village

The definition of cultural village is varying. Irwanti et al. (2017) and Sukariyanto (2015) define cultural village as development of a village in the form of integration between attractions, accommodation and supporting facilities presented in the community life structure. Cultural village is a rural area that offers a whole atmosphere that reflects the authenticity of the countryside, both in terms of social culture, customs, daily life, traditional architecture, village spatial structure, and has the potential to be developed various components of tourism, for example: attractions, accessibility, amenities and ancillary. The cultural village is a form of integration between attractions, accessibility, amenities and ancillary presented in a community life structure that blends with the prevailing rules and traditions. Attractions are the combination of natural, cultural and specific attractions that allows the integration of tourists as active participation on the local people daily activities such as dance courses, language and others specific activities related to culture (Andrianto and Sugiama, 2016). Accessibility is the supporting transportation to reach the cultural village including infrastructure and services. Amenities are accommodation, guides, food and beverages, and tourist information center. Ancillary covers the relationship between cultural village and regulatory institutions such as tourism boards, tourism authority, tourism associations, and tourism communities. According to Syafi'i and Suwandono (2015), to be a cultural village, a village must meet several requirements, among others as follows: (1) good accessibility, easy for tourists to visit by using various types of transportation; (2) 
have interesting objects such as nature, cultural arts, legends, local food, and so to be developed as a tourist attraction; (3) the community and village officials receive and give high support to the cultural villages and tourists who visit their village; (4) security in the village is assured; (5) adequate accommodation, telecommunications, and manpower are available; (6) it is either cold or cool; and (7) related to other tourism objects already known by the public.

\section{Defining Cultural Tourist}

A cultural tourist is defined as someone to visit or intends to visit a cultural tourist attraction, art gallery, museum or historic site, attend a performance or festival, or participate in a wide of other activities at any time during their trip, regardless of their main reason for travelling (McKercher, 2002). McKercher (2002) introduce the types of cultural tourist: (1) the purposeful cultural tourist (high centrality/deep experience)-learning about the other's culture or heritage is a major reason for visiting a destination and this type of cultural tourist has a deep cultural experience; (2) the sightseeing cultural tourist (high centrality/shallow experience)-learning about other's culture or heritage is a major reason for visiting a destination, but this type of tourist has a more shallow, entertainment oriented experience; (3) the casual cultural tourist (modest centrality/shallow experience)-cultural tourism reasons play a limited role in the decision to visit a destination and this type of cultural tourist engages the destination in a shallow manner; (4) the incidental cultural tourist (low centrality/shallow experience)-cultural tourism plays little or no meaningful role in the destination decision-making process, but while at the destination, the person will participate in cultural tourism activities, having a shallow experience; (5) the serendipitous cultural tourist (low centrality/deep experience)-cultural tourism plays little or no role in the decision to visit a destination, but while there, this type of cultural tourist visits cultural attractions and ends up having a deep experience.

\section{RESEARCH METHODOLOGY}

This research had been done utilizing qualitative research with case study approach to seeking for opinion or facts that lays in the real context (Thornhill et al., 2012; Yin, 2009). Data was gathered through in-depth interview with the informants from the management of tourist destination and local tourism related businesses (Thornhill et al., 2012; Yin, 2009). The list of questions is drawn from attraction, accessibility, amenities, and ancillary. The number of informants was 23 persons from two villages. Observation and document review were also used for the sake of data triangulation (Thornhill et al., 2012; Yin, 2009). Data was analyzed following Miles and Huberman (1994) method: Data reduction, data display and conclusion drawing (Sarantakos, 2012). The cases for conducting research was took place in Pemuteran Village, Buleleng Regency and Kamasan Village, Klungkung Regency. The information from data analysis then presented in the form of Strengths, Weaknesses, Opportunities and Threats (SWOT) of each cultural village.

\section{RESULTS}

Pemuteran Village

Pemuteran is a village with interesting natural long coastal with black sandy beach (Figure 1). Pemuteran Village is located on the west coast of Bali, approximately $55 \mathrm{~km}$ West of Singaraja city or $200 \mathrm{~km}$ from Denpasar. It lies between the clusters of hills and the sea to make this place beautiful and quiet, away from the crowds. The beach in Pemuteran is one of the beaches visited by many tourists in North Bali. Black sand stretches approximately $6 \mathrm{~km}$ framed by blue skies and clear seas with a wealth of coral reefs. Coral reefs at Pe muteran beach can be explored by snorkeling not far from the beach. Pemuteran Village 
has the widest shallow coral reef area in Bali with the safe and quiet waved. Previously, the main job of the local community as source of living was fishermen until 1992 when the first hotel was built.

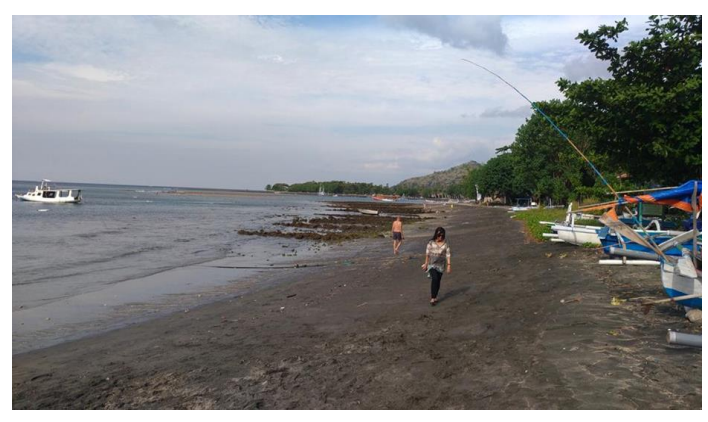

FIGURE 1 . Pemuteran beach

Attractions: The main attraction of Pemuteran Village is exploring the activities of maritime tourism such as snorkeling and diving. This is due to the nature of Pemuteran that has beautiful coastal scenery with the view of both mountain and beach which have coral reefs rich with coral species. The atmosphere is relatively quiet and comfortable for tourists to enjoy. The local community is actively involved in the tourism business by preserving the coral reef from the damage managed by Karang Lestari Foundation. Before, the fishermen damage the coral reef by using inappropriate method for fishing i.e., bombing to catch the fish. With this method, not only kills the fish but also other species and coral reefs which are the habitat for the growth of marine ecosystems. The preservation of coral reefs movement was started in 1989 and in 1992 already showing the results. Coral reefs are starting to grow well and tourists started to visit. The first hotel then was built to change the source of local community income and lessen the number of fishermen. This was the starting point of Pemuteran Village becoming a tourist destination. The adoption method is used to finance the coral reefs development. The tourists and other community donate certain amount of money for the development of one coral reef in which by this they are directly participate in preserving the environment for sustaining Pemuteran as cultural village destination. The diving activities are managed by the village in cooperation with third parties as operators to protect and reduce the excessive exploitation. Pemuteran Village engages tourists to the coral reefs preservation as one of the strategy to develop sense of belonging to gain repeat and loyal tourist and spread good words of mouth. These will support Pemuteran to maintain its sustainability. The thing that supposed to be improved is the cleanliness of the beach. The waste management needs to be given more attention (Figure 2). The road map of management and strategy of Pemuteran shows the success of management policy change by strategic change, which all integrated in a policy, rule and law. In the 80's when the local fishermen sought fish still in a destructive ways is changed to a green and nurturing environment. This is possible because of massive involvement of all communities. This shows that involving community strategy and nurturing environment policy can lead to the success of cultural village management. 


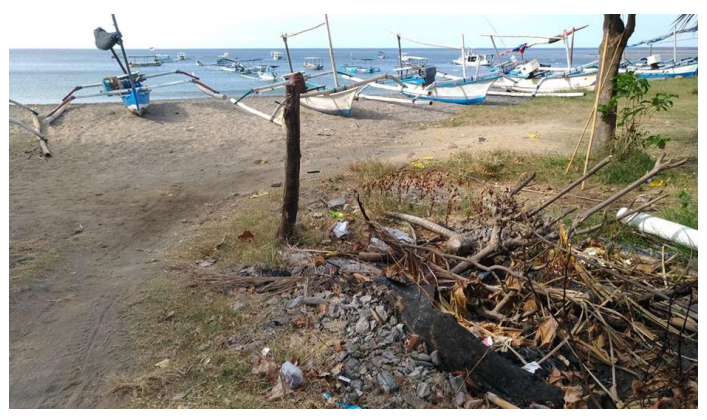

FIGURE 2 . Garbage by the beach

Accessibility: Pemuteran is easy to access because it is located along the main road. However, some of the road towards to the beach is left unmaintained and also blocked by some hotels. Lack of signage to the beach also often leads tourist end up into a dead end road belonging to those big hotels.

Amenities: In 2015, the number of accommodations as the tourism support facilities was 18 including homestay, bungalows, and inns, 10 hotels or resorts, and 5 villas (Kompas, 2015). The homestay, bungalows and inns should be owned by local people according to the local regulation. This is to support and provide opportunity for local people to improve their prosperity as the fundamental issue of CBT. Other supporting facilities are 20 cafes or restaurants, 14 diving service companies and 8 spas. Tourism business related also develops such as handicraft and culinary industries. For handicraft, there is no specifics souvenir that relate to Pemuteran as tourist destination as the memorable from Pemuteran. As Udayakumar (2016) states that tourists tend to take something home from places that they visit as a memorable souvenir.

Ancillary: The relation of Pemuteran with tourism stakeholders such as tourism authority (local and national) is relatively close proven by regular visitation from the representative of tourism authority to monitor and control the improvement of the coral reefs projects.

\section{Pemuteran village SWOT analysis}

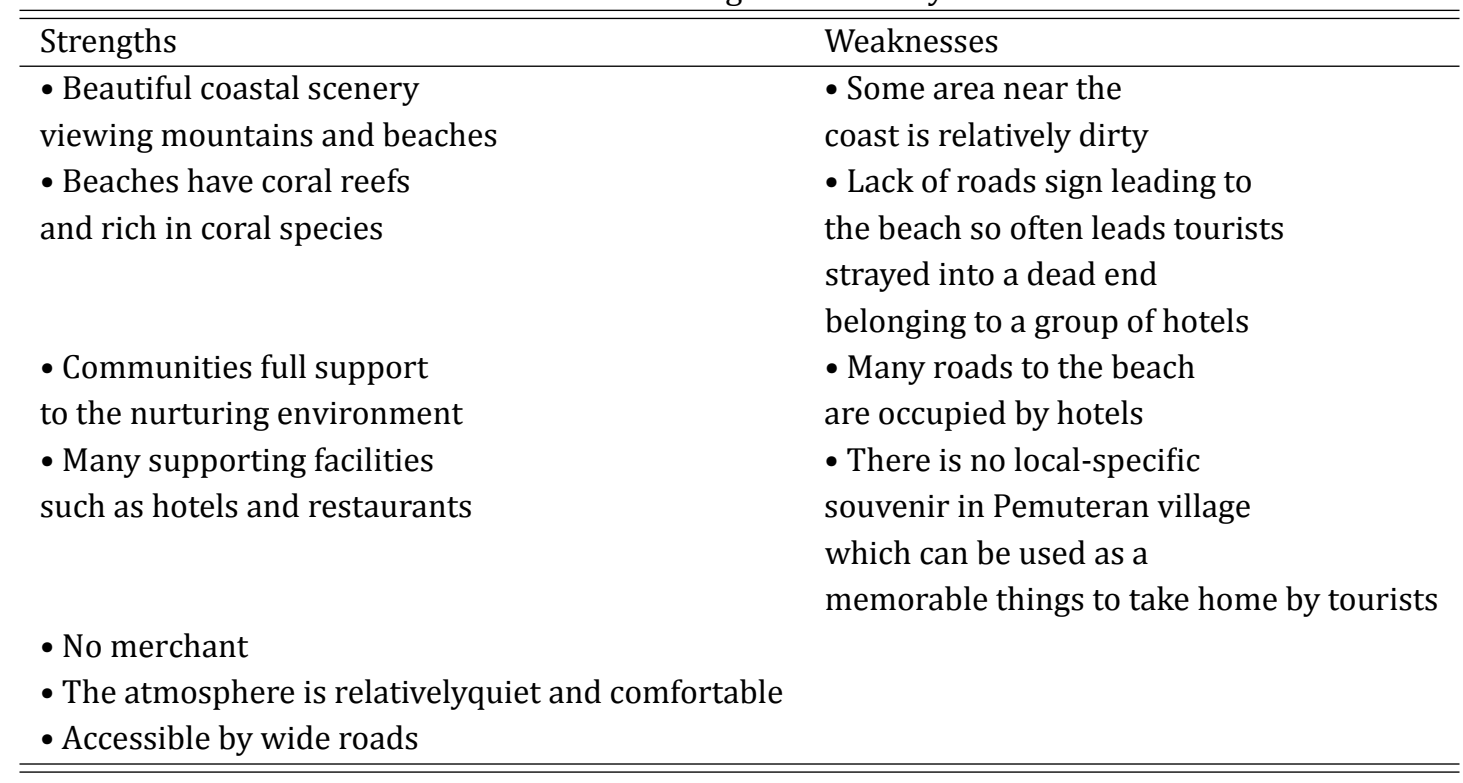


Pemuteran village SWOT analysis (Continue...)

\begin{tabular}{ll}
\hline \hline Opportunities & Threats \\
\hline \hline - Developing promotion for local Meeting, & ・ If the beach atmosphere is left \\
Incentive, Conference and Exhibition (MICE) & dirty it may cause tourists \\
industry as there are relatively & $\begin{array}{l}\text { to switch to other } \\
\text { similar cleaner beach. }\end{array}$ \\
$\begin{array}{l}\text { sufficient facilities } \\
\text { to thstall road signs for road leading }\end{array}$ & \\
• Increasing number of green tourists & \\
\hline \hline
\end{tabular}

\section{Kamasan Village}

Kamasan is a village located right South of Semarapura city, Klungkung Regency. Kamasan Village is only about 249 hectares with a population of about 3,400 people and spread over 10 banjar adat or 4 government hamlets. Kamasan Village is only $4 \mathrm{~km}$ away from Semarapura city, which is the capital of Klungkung Regency. Although categorized as a small village but Kamasan is called as the parent of Balinese wayang kulit (puppet) painting (Figure 3). In the historical data, Kamasan also recorded the journey of colored painting in Bali. In fact, the region is famous as the producer of classical puppet painting artwork which is the work of the artists in Kamasan Village. Kamasan is a community of traditional painting artists. It has a consistent traditional painting style, therefore artists call Kamasan has its own traditional Kamasan paintings style. Besides, other art talent is also growing in Kamasan such as gold and silver carving and the last is the art of carving a bullet. Although, in terms of material used to follow the changes, the trademark or style is depicting wayang figures still remain. The development of economy and industry leads changes on the type of job and employment. This changes also happened to the Kamasan population which threatening the sustainability of the Kamasan traditional life. Many of Kamasan youths decide to pursue so called a modern job such as office worker or nurse.

Attractions: The main attraction of Kamasan Village is handicraft made by the local people particularly puppet painting with unique pattern specific belong to Kamasan and carving. The tourists who come to Kamasan have specific interest towards traditional painting and more likely to spend a couple of days to learn and practice how to create puppet painting or other crafts. Visitors can also watch directly the process of making carvings and/or paintings in the artists' workshop and can also order directly the painting.

Amenities: Some local paintings home industry has been providing room inn or homestay to accommodate tourists who willing to stay in the village. This local accommodation enable them to stay for some days to enable them to observe and enjoy the production process of the paintings, goldsmith, silversmith etc. Local people provide homestay accommodation to give ultimate one stop service to the visitors.

The Kamasan atmosphere and its suroundings is relatively clean compare with other area in Klungkung (Figure 4). The road is clean and in good maintainance. Also there are cozy pedestrian for tourist who is willing to walk around for exploring the village.

Accessibility: The location of the village is not far both from Semarapura as the regency capital and Denpasar as the province capital. This strategic location could overcome the facilities drawback of the village such as big restaurants, banks, hospitals etc. Nevertheless the transportation infrastructure and services are becoming the main concern of the local government The local government has contributed in supporting the public facilities 
by providing road enhancement, cleaning service officers and some other public facilities. Ancillary: A Corporate Social Responsibility (CSR) program by the Ministry of StatedOwned Enterprises (SOE) is established right in the center of the village helps marketing of the village products. The CSR helps to promote the product worldwide by using the flat form of Information and Communication Technology (ICT). This supports the sustainability of the local tradition indirectly. However the office is often left vacant or unattended. The head of Klungkung Regency said that the existence of this CSR has helped to excite artisans and artists to develop creative economic enterprise. This is one strategy to keep and enhance the sustainability of Kamasan local culture. A state-owned bank (Bank Negara Indonesia) offer a non-commercial credit with a very low interest rate. It's aimed to increase the class of the enterprises.

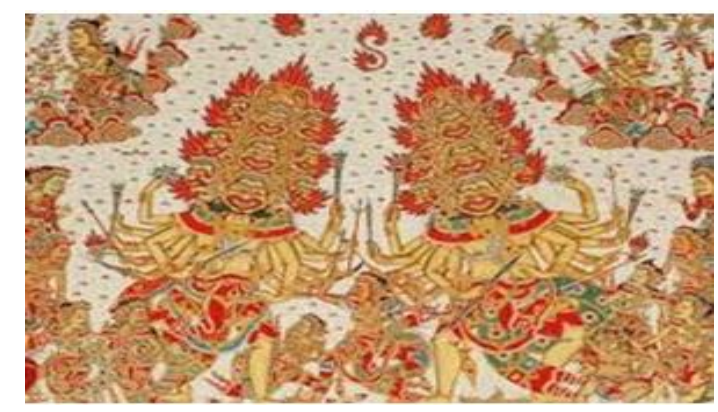

FIGURE 3 . Kamasan painting courtesy of museum nyoman gunarsa

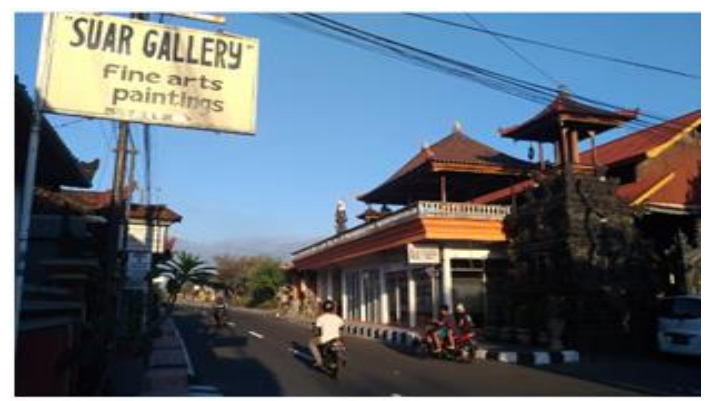

FIGURE 4. One corner of kamasan village

The following is the pemuteran village SWOT analysi

\begin{tabular}{|c|c|}
\hline Strengths & Weaknesses \\
\hline $\begin{array}{l}\text { - It is well known as the center of } \\
\text { traditional Balinese painting } \\
\text { (particularly puppet painting). } \\
\text { - Good accessibility near Klungkung city } \\
\text { - The village is clean and tidy }\end{array}$ & $\begin{array}{l}\text { - It has marketing assistance } \\
\text { by the Ministry of SOEs, } \\
\text { however the staff are rarely in place }\end{array}$ \\
\hline Opportunities & Threats \\
\hline $\begin{array}{l}\text { - It can be a marketing agent } \\
\text { of handicrafts from other regions }\end{array}$ & $\begin{array}{l}\text { - The profession of population who were } \\
\text { traditionally and hereditary as } \\
\text { painters, now it is gradually changing to } \\
\text { other professions such as nurse and others. }\end{array}$ \\
\hline
\end{tabular}




\section{DISCUSSION}

Findings reveal that the apparent difference between Pemuteran and Kamasan is the type of cultural tourists visiting this village. In Pemuteran, the type of cultural tourist according to the typology of McKercher (2002) is matched with purposeful, sightseeing and casual cultural tourist. However, the majority of these three type of cultural tourist is sightseeing followed by casual and purposeful cultural tourist respectively. Most of the tourists want to learn and experience about Pemuteran culture attraction in this case adventurous tourism activities such as snorkeling and diving with more entertainment oriented. Meanwhile some tourists just want to have fun with no intention to learn about local culture. Only a few numbers of tourists has an intention to learn and experience the local culture by adopted coral reefs to sustain the environment, therefore this type of cultural tourist don't pretty much participate to the development of community roles. A relatively huge ratio of hotels over the homestays in Pemuteran also shows the less of community involvement. The relationship of the local people and tourist are artificial not personal. Although, it is difficult to be justified. Pemuteran management strategy development is then accommodating the majority of tourists by providing cultural tourism activities to more entertainment oriented. The tour packages offer outdoor activities such as diving, snorkeling and trekking. In relation with strengths and weaknesses of Pemuteran, the strategy should be developed are: (1) sustain and increase the community and tourists participation in nurturing coral reefs; (2) improve the accessibility of to the beach; and (3) provide the souvenir unique to the cultural village. Comparing between opportunities and threats of Pemuteran, the strategy are: (1) educate local people to the importance of waste management system; (2) promote the environmentally friendly tourist destination to attract green tourists; and (3) train local tour guides and operators. Salazar (2012) stated that local guides are the key importance factor in the CBT because they know better the cultural heritage that shoud be protected to maintain sustainabilitynand have better understanding about local issues.

\section{CONCLUSION}

In Kamasan, the type of tourists is more to purposeful cultural tourists. The tourists are seeking for deep cultural experience to learn about the other's culture. They more likely to stay close learning the culture. Most tourist who visit Kamasan spend more time to learn how to do the puppet painting and learn about the history behind the painting. They engage closely with the artists. The concept of homestay as an accommodation is the most suitable. This is supported by local government plan to improve the number of homestay in Kamasan and train local people to run the homestay. Therefore, Kamasan is not the place for experiencing outdoor activities. The area is quite and no night life activities. Kamasan authority tries to leave the destination as original as it is and oppose the commercialization. The craft is targeted to be imported to benefitted local community as craft (particularly puppet painting) is consider expensive and has narrow target market (Richards, 2002). Kamasan should increase the market by reaching potential cultural tourists utilising new technology. The strategic development proposed after considering the strengths and weaknesses of Kamasan are: (1) sustain the clean environment; (2) improve the partnership with cultural tourists and buyers; and (3) improve the more interesting of tourist's attractions to invite tourists to visit. Related to improve tourist attractions, creative tourism in which tourists learning a specific skills belongs to the cultural village is more likely suit to Kamasan Village (Jovicic, 2016). Short cources programs related to painting, carving, and gastronomy should be developed in more creative ways. The strategic development proposed after considering the strengths and weaknesses of 
Kamasan are: (1) sustain the clean environment; (2) improve the partnership with tour operators; and (3) improve the more interesting of tourist's attractions to invite tourists to visit. Meanwhile the strategy to consider opportunity and threats of Kamasan are: (1) introduce young people to the importance of sustaining the heritage; (2) improve the income by thinking creatively to create cheaper handicraft; and (3) improve the partnership with tour operators.

\section{LIMITATIONS AND RECOMMENDATIONS}

The suggestion for further research is to measure quantitatively the success of the implementation of cultural village initiative in Indonesia following the criterias proposed by Goodwin and Santilli (2009) that are Social Capital and Empowerment, Local Economic Development, Livelihoods, Conservation/Environment and Commercial Viability.

\section{ACKNOWLEDGEMENT}

This paper is part of the research findings under Eminent Applied Research of Higher Education scheme that funded by Ministry of Research, Technology and Higher Education of Republic of Indonesia 2017.

\section{REFERENCES}

Andrianto, Tomy, and Gima Sugiama. 2016. The analysis of potential 4A's tourism component in the Selasari rural tourism, Pangandaran, West Java. Paper presented at the Asia Tourism Forum 2016-The $12^{\text {th }}$ Biennial Conference of Hospitality and Tourism Industry in Asia, Bandung, Indonesia.

Aref, Fariborz, and Ma'rof B. Redzuan. 2009. Community capacity building for tourism development. Journal of Human Ecology 27, no. 1: 21-25. DOI: 10.1080/09709274.2009.11906187

Bahaire, Tim, and Martin Elliott-White. 1999. Community participation in tourism planning and development in the historic city of York, England. Current Issues in Tourism 2, no. 2-3: 243-276. DOI: 10.1080/13683509908667854

Boonratana, Ramesh. 2010. Community-based tourism in Thailand: The need and justification for an operational definition. Kasetsart Journal: Social Sciences 31, no. 2: 280-289.

Goodwin, Harold, and Rosa Santilli. 2009. Community-based tourism: A success. URL: goo.gl/6NwgTh (accessed on March $2,2017)$.

Goodwin, Harold. 2002. Local community involvement in tourism around national parks: Opportunities and constraints. Current Issues in Tourism 5, no. 3-4: 338-360. DOI: 10.1080/13683500208667928

Hiransomboon, Katanyu. 2017. Using convenience store service of foreign backpacker tourists in Bangkok, Thailand. In- $\quad$ ternational Jorunal of Business and Economic Affairs 2, no. 1: 1-7. DOI: 10.24088/ijbea-2017-21001

Irwanti, Ni Ketut Dewi, and I. Wayan Arta Artana. 2017. Strategi pengembangan Desa Belimbing sebagai desa wisata di kecamatan pupuan tabanan-Bali. Jurnal Perhotelan dan Pariwisata 3, no. 2: 77-91.

Jovicic, Dobrica. 2016. Cultural tourism in the context of relations between mass and alternative tourism. Current Issues

in Tourism 19, no. 6: 605-612. DOI: 10.1080/13683500.2014.932759

Kompas. 2015. Pemuteran, kawasan nelayan jadi desa wisata internasional. URL: goo.gl/1jFyFg (accessed on April $10,2017)$.

Kompas. 2016. Indonesia memiliki 150 desa wisata. URL: goo.gl/NQ9C4s (accessed on April 25, 2016).

Kompas. 2017. Bali genjot 100 desa wisata tahun ini. URL: goo.gl/JaGTuQ (accessed on April 25, 2016).

Kontogeorgopoulos, Nick, Anuwat Churyen, and Varaphorn Duangsaeng. 2014. Success factors in community-based tourism

in Thailand: The role of luck, external support, and local leadership. Tourism Planning \& Development 11, no. 1:

106- 124. DOI: $10.1080 / 21568316.2013 .852991$

Lucchetti, Veronica Garcia, and Xavier Font. 2013. Community based tourism: Critical success factors.

URL: https://goo.gl/L1qAwM (accessed on December 25, 2017).

McKercher, Bob. 2002. Towards a classification of cultural tourists. International Journal of Tourism Research 4, no. 1:

29-38. DOI: $10.1002 /$ jtr.346

ISSN: $2414-3111$

DOI: 10.20474 /jahss-3.6.1 
Miles, Matthew B., and A. Michael Huberman. 1994. Qualitative data analysis: An expanded sourcebook. London, UK: Sage Publication.

Ministry of Domestic Affair. 2017. Indonesia incorporated: 20.000 homestay desa wisata pada tahun 2017.

URL: goo.gl/LWWHen (accessed on December 1, 2017).

Niesing, CM, S. Van Der Merwe, and DM Potgieter. 2016. The impact of income-generating projects on stimulating the de- velopment of entrepreneurial activities in communities: The holding hands case. International Journal of Business and Economic Affairs 1, no. 1: 36-46. D0I: 10.24088/ijbea-2016-11006

Okazaki, Etsuko. 2008. A community-based tourism model: Its conception and use. Journal of Sustainable Tourism 16, no. 5: 511-529. DOI: $10.2167 /$ jost782.0

Pathumporn, Jinnapas, and Suganda Nakapaksin. 2015. Participatory action research model for sustainable community based tourism development. International Journal of Business and Administrative Studies 1, no. 3: 89-93.

DOI: $10.20469 /$ ijbas.10002-3

Richards, Greg. 2002. Tourism attraction systems: Exploring cultural behavior. Annals of Tourism Research 29, no. 4: 1048-1064. DOI: 10.1016/s0160-7383(02)00026-9

Salazar, Noel B. 2012. Community-based cultural tourism: Issues, threats and opportunities. Journal of Sustainable Tourism 20, no. 1: 9-22. DOI: 10.1080/09669582.2011.596279

Sarantakos, Sotirios. 2012. Social research. Hampshire, UL: Palgrave Macmillan.

Sukariyanto, I Gede Made. 2015. Partisipasi Masyarakat Lokal dalam Pengembangan Desa Belandingan sebagai desa wisata di Kabupaten Bangli. Undergraduate thesis, Skripsi Sarjana Badung, Sekolah Tinggi Ilmu Pariwisata Bali, Bali, Indonesia.

Syafi'i, Muhammad, and Djoko Suwandono. 2015. Perencanaan desa wisata dengan pendekatan konsep Community Based Tourism (CBT) di desa bedono, kecamatan sayung, kabupaten demak. Ruang 1, no. 2: 51-60.

DOI: $10.14710 /$ ruang.1.4.221-230

Thornhill, Adrian, Saunders Mark Nk, and Lewis Philip. 2012. Research methods for business students. Edinburgh, UK: Pearson Education Limited.

Timothy, Dallen J., and Cevat Tosun. 2003. Arguments for community participation in the tourism development process. Journal of Tourism Studies 14, no. 2: 2-15.

Tosun, Cevat. 2006. Expected nature of community participation in tourism development. Tourism Management 27, no. 3: 493-504. DOI: 10.1016/j.tourman.2004.12.004

Tosun, Cevat. 2000. Limits to community participation in the tourism development process in developing countries. Tourism Management 21, no. 6: 613-633. DOI: 10.1016/s0261-5177(00)00009-1

Udayakumar, Prasanth. 2016. The role of traditional handicrafts in promoting rural tourism: A study on pipli rural tourism village in the state of Odisha. In Responsible tourism \& human accountability for sustainable business, eds. Ramesh Kumar Miryala, and Jayaprakash Narayan Gade, Hyderabad, India: Zenon Academic Publishing.

Yin, Robert K. 2009. Case study research: Design and methods. Thousand Oaks, CA: SAGE publications.

Yusof, Yusnita, Yahaya Ibrahim, Mohd Shaladdin Muda, and Wan Abd Aziz Wan Mohd Amin. 2012. Community based tourism and quality of life. Review of Integrative Business and Economics Research 1, no. 1: 336-346.

— This article does not have any appendix. - 